International Journal of Advanced Academic Studies 2021; 3(4): 30-36

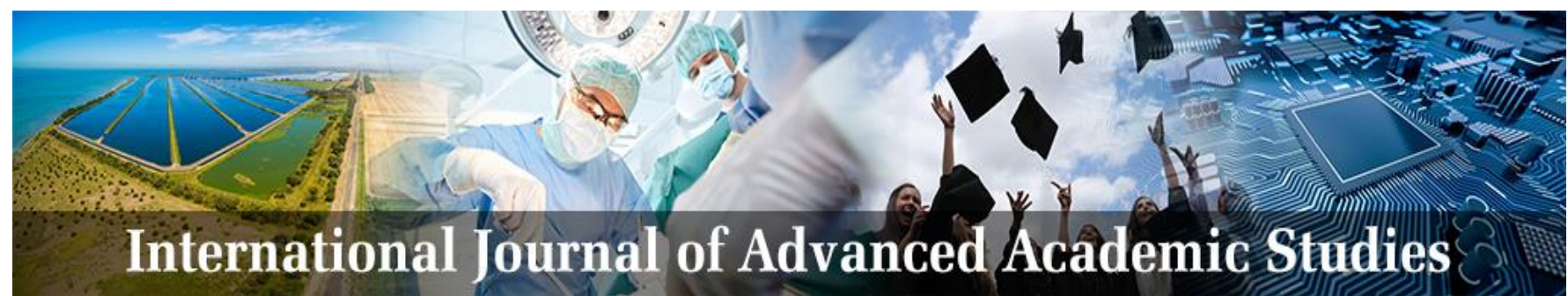

E-ISSN: 2706-8927

P-ISSN: 2706-8919

www.allstudyjournal.com

IJAAS 2021; 3(4): 30-36

Received: 16-04-2021

Accepted: 23-06-2021

عبدالصبور صالح

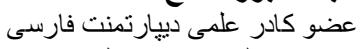
بو هنتون تعليم و تربيه كابل

ميرويس شمال

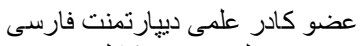
بو هنتون تعليم و تربيه كابل

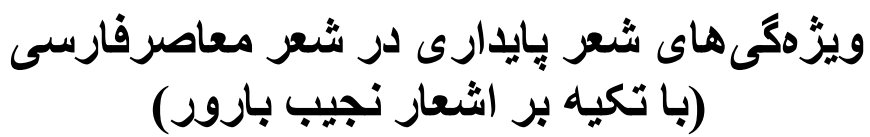

عبدالصبور صالح ريرويس شمال

DOI: https://doi.org/10.33545/27068919.2021.v3.i4a.631

جكيدان

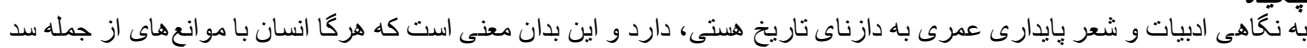

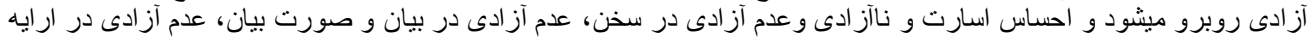

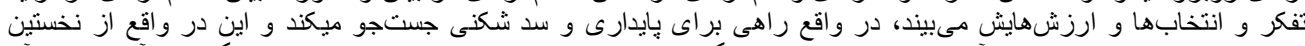

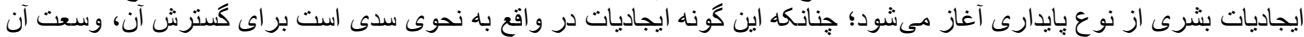

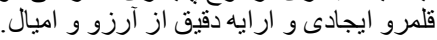

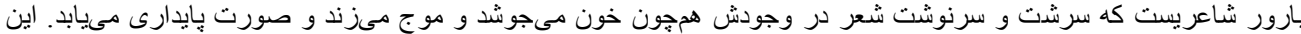

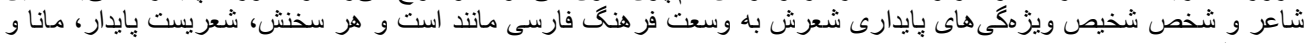

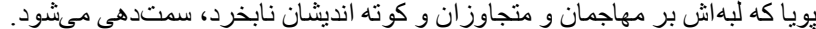

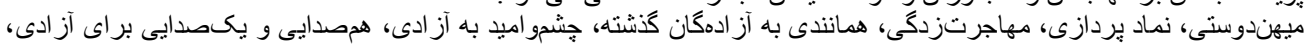

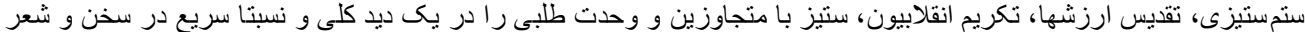

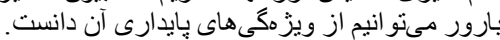

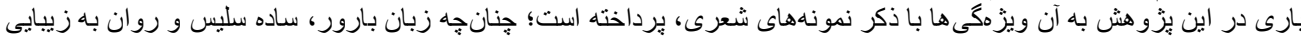

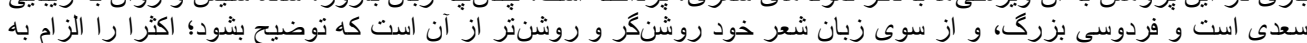
توضيح نمىدانيم همين بس كله بخو انيم.

كليد وازه: نجيب بارور، شعر بايدارى، ادبيات بايدارى، شعر معاصر افغانستان.

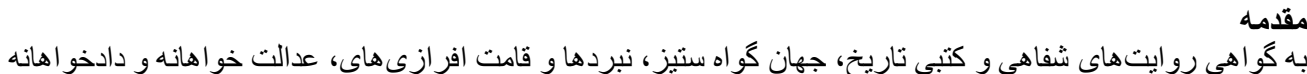

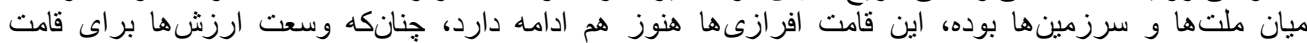

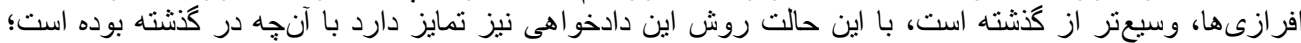

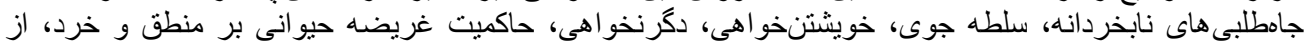

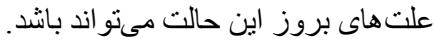

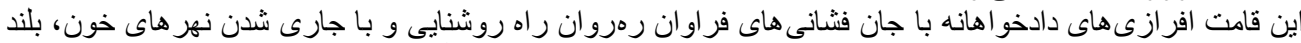

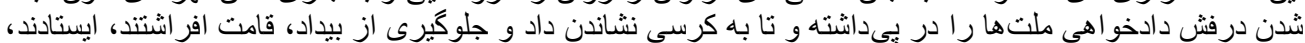

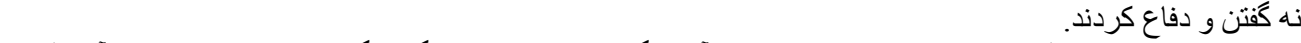
وقايع مهم تاريخ ساز ملت ها كه با سرشت و سرنوشت آن ها كره خورده است به كونه كسترده، لايه هاى هستى آن ملتها

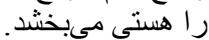

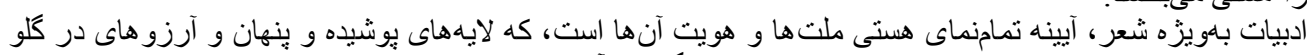

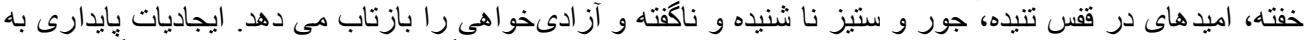

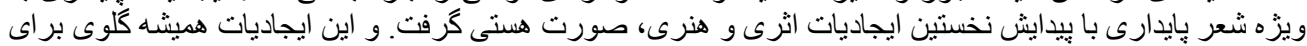

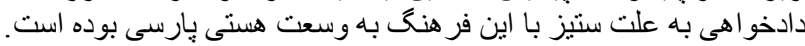

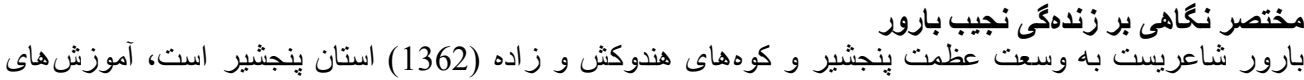

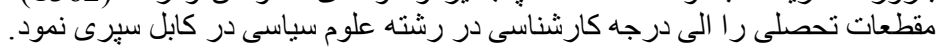

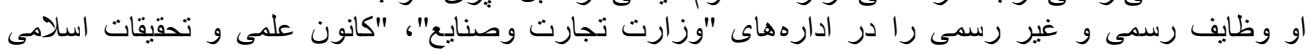

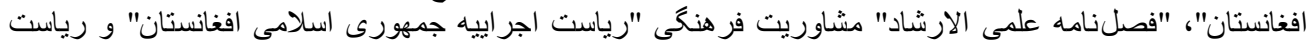

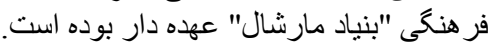

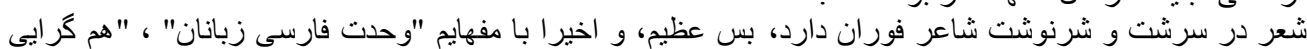

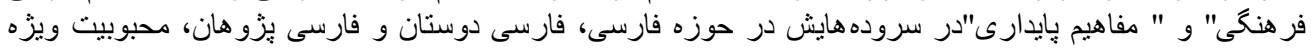

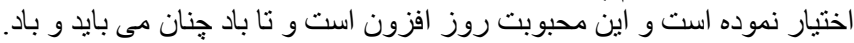

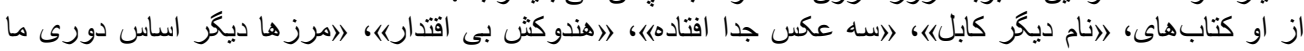

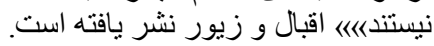

Corresponding Author: عبدالصبور صالح

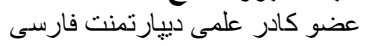
إيو هنتون تعليم و تربيه كابل

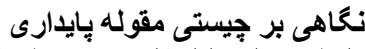

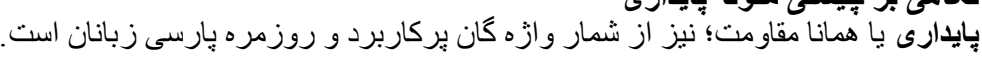




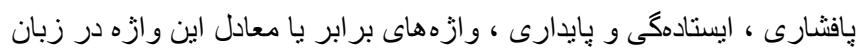

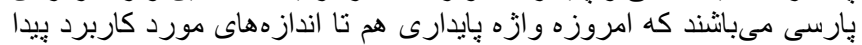

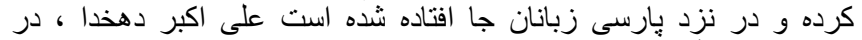

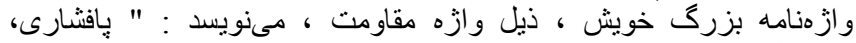

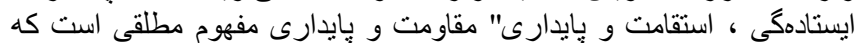

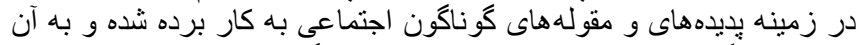

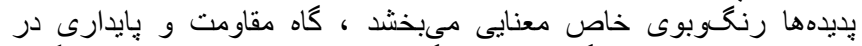

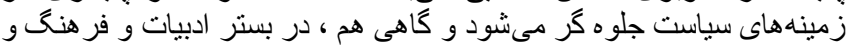

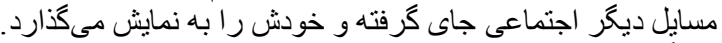

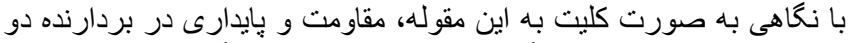

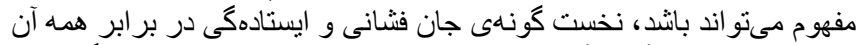

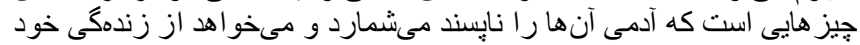

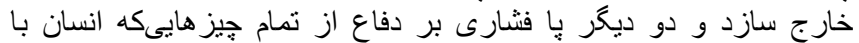

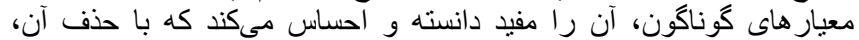

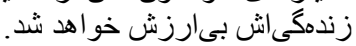

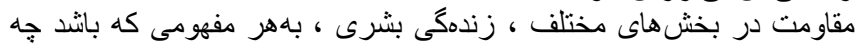

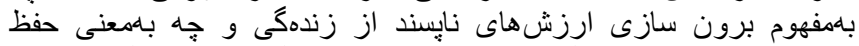

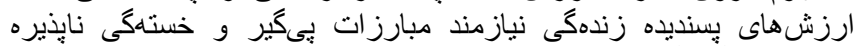

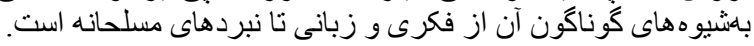

جيستى ادبيات بإيدارى

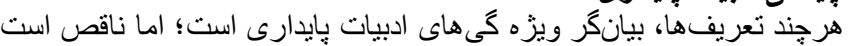

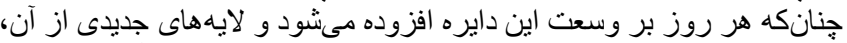

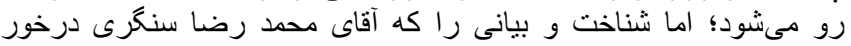

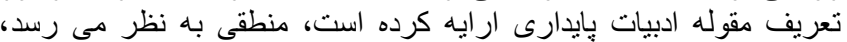

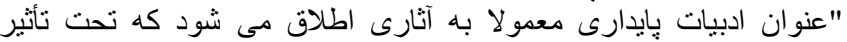

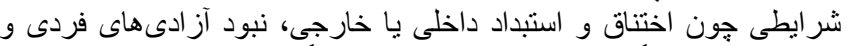

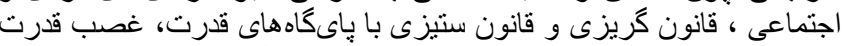

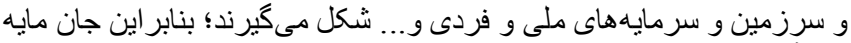

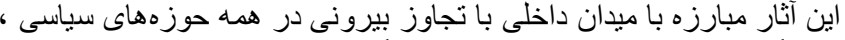

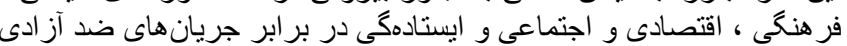

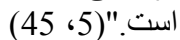

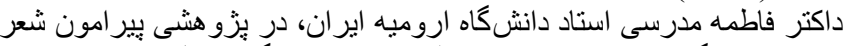

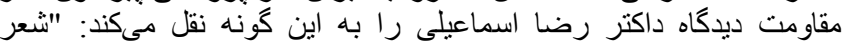

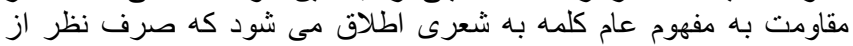

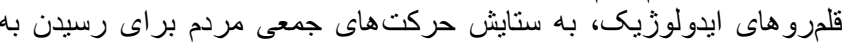

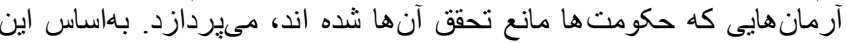

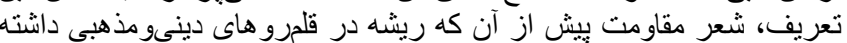

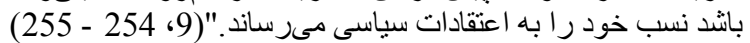

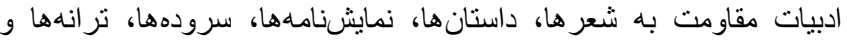

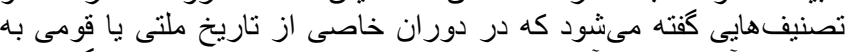

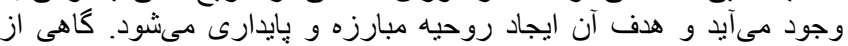

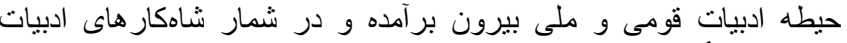

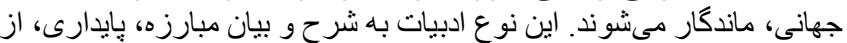

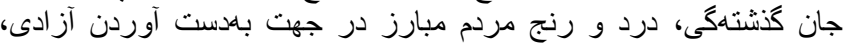

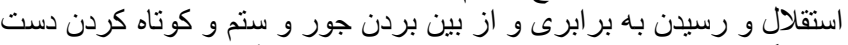

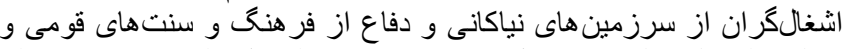

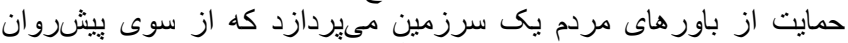

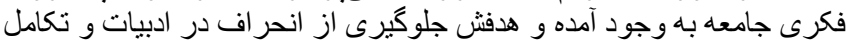

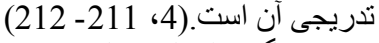

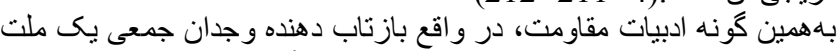

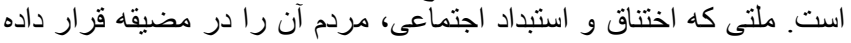

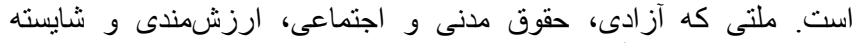

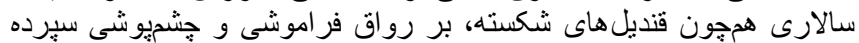

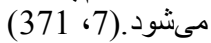

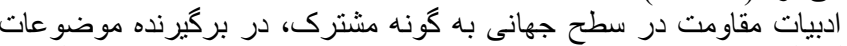

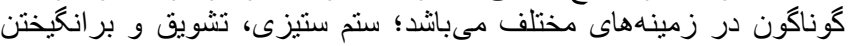

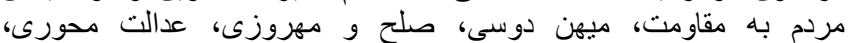

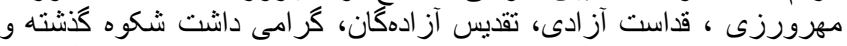

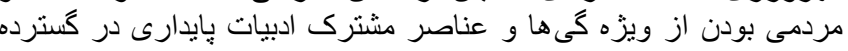

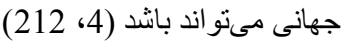

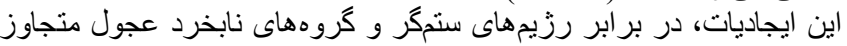

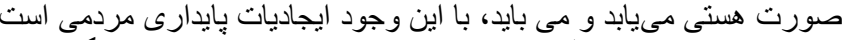

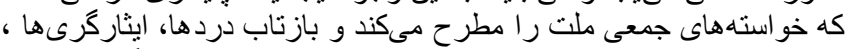

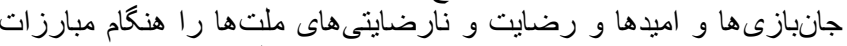

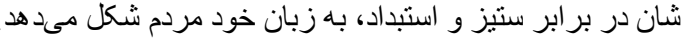

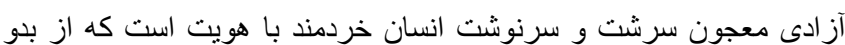

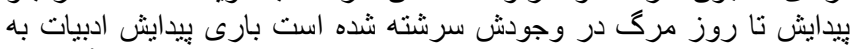

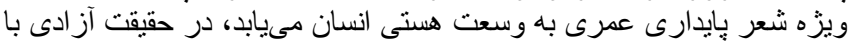

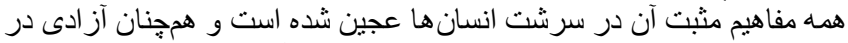

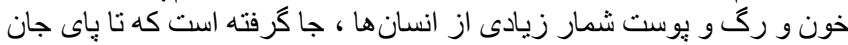

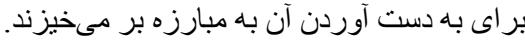

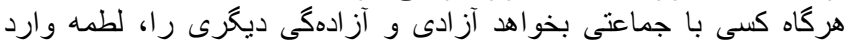

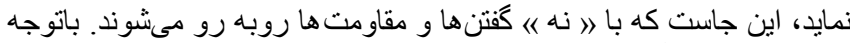

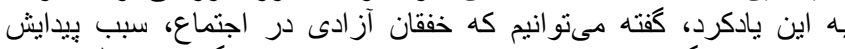

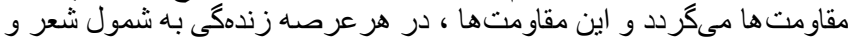

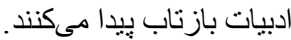

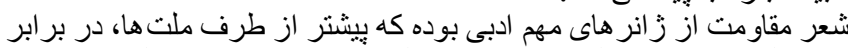

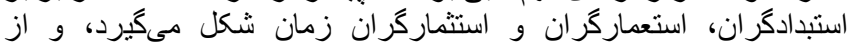

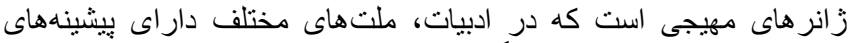

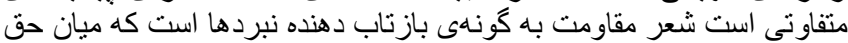

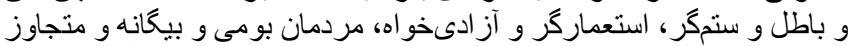

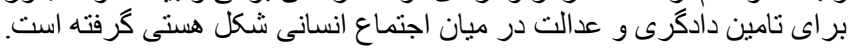

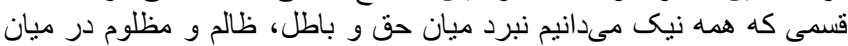

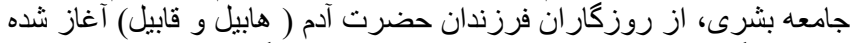

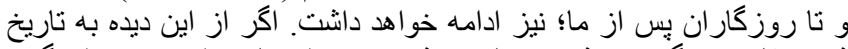

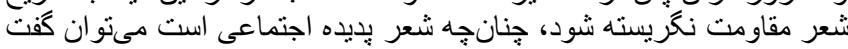

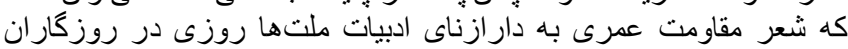

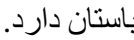

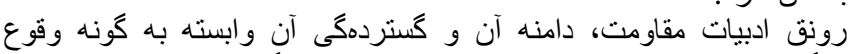

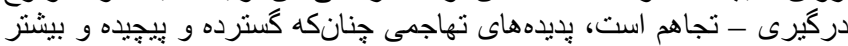

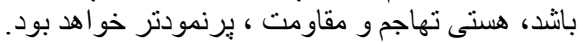

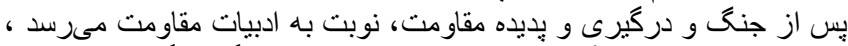

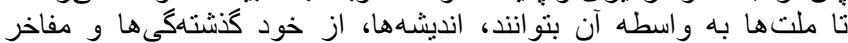

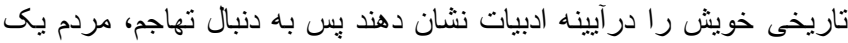

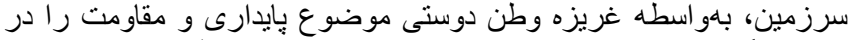

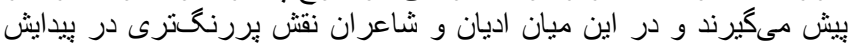

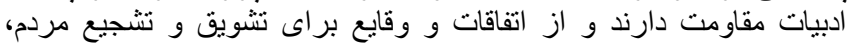

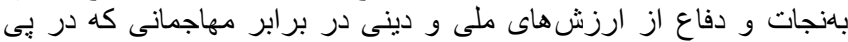

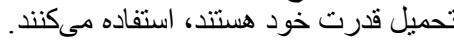

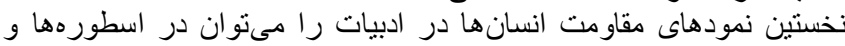

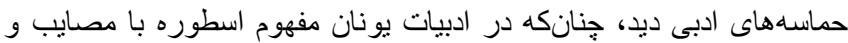

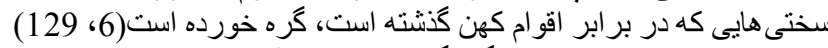

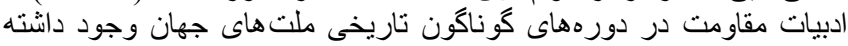

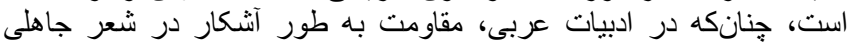

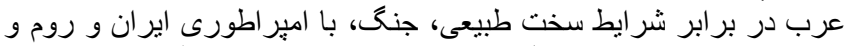

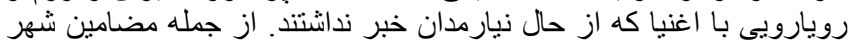

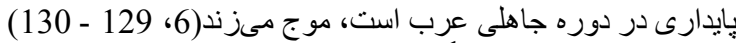

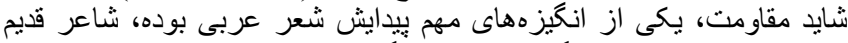

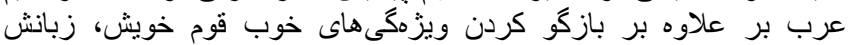

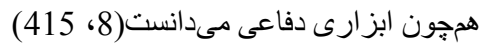

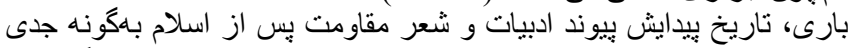

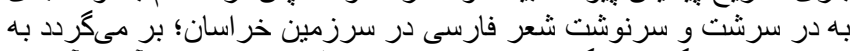

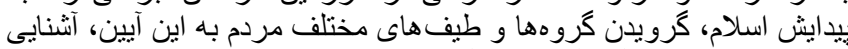

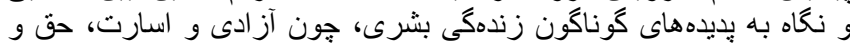

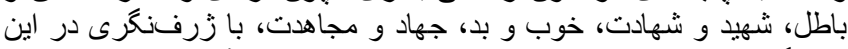

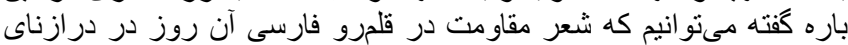

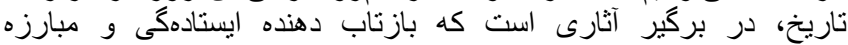

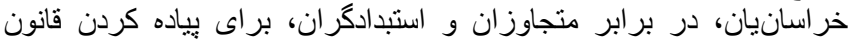

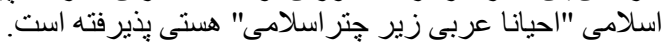

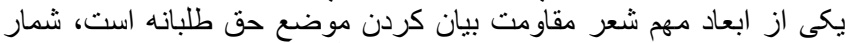

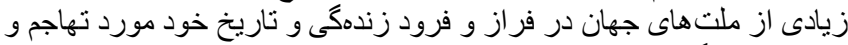

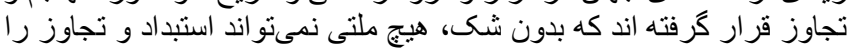

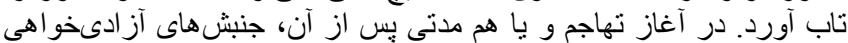

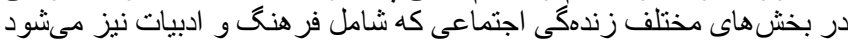

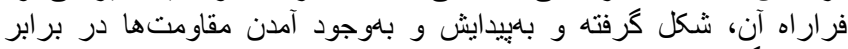

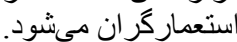

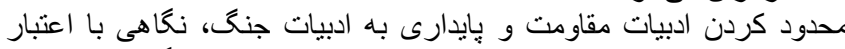

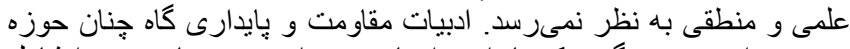

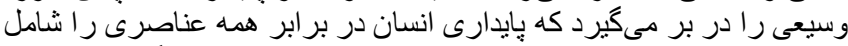

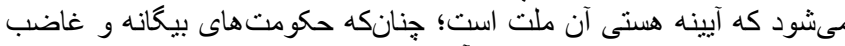

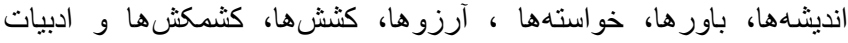




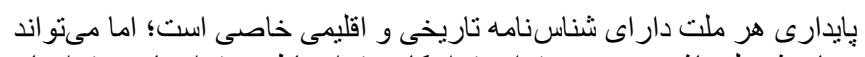

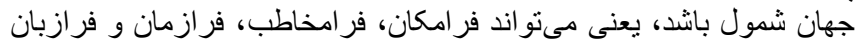

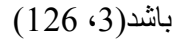

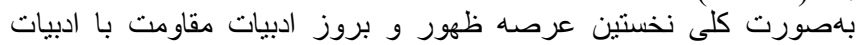

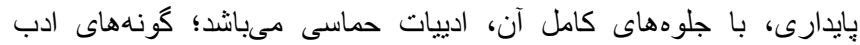

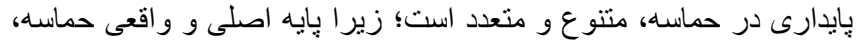

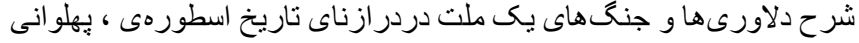

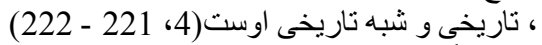

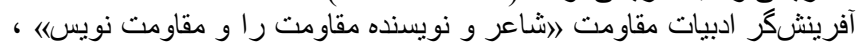

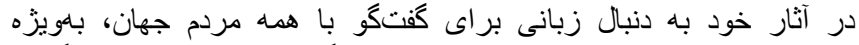

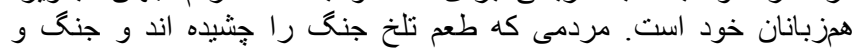

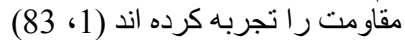

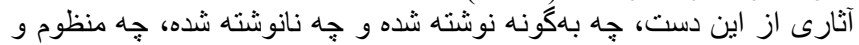

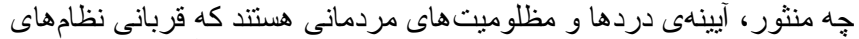

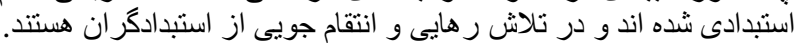

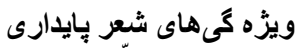

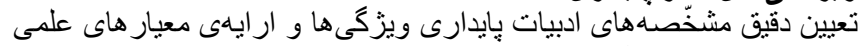

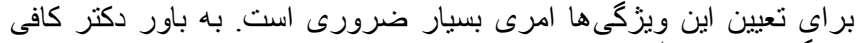

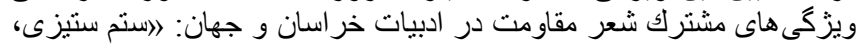

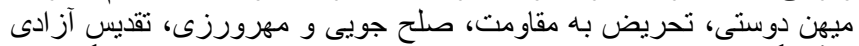

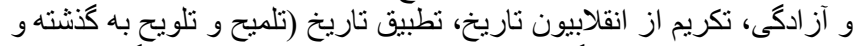

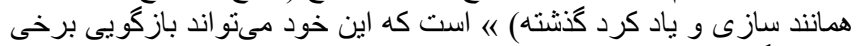

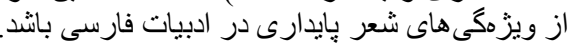

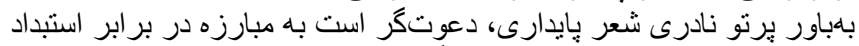

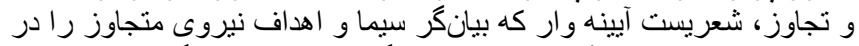

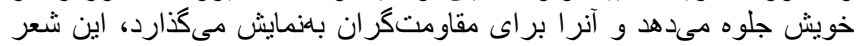

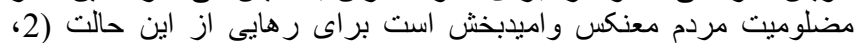

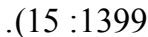

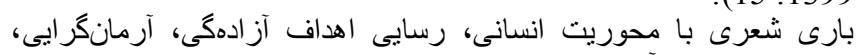

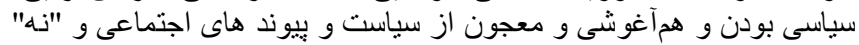

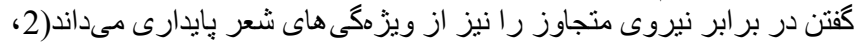

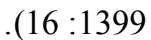

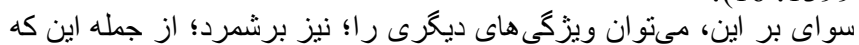

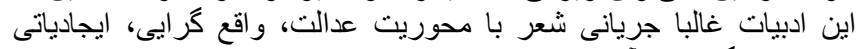

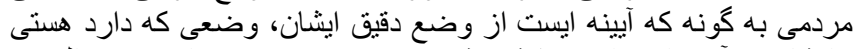

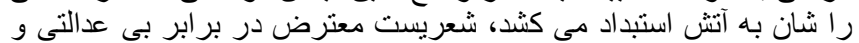

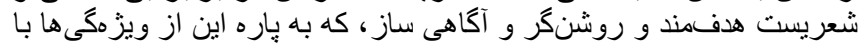

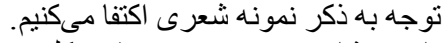

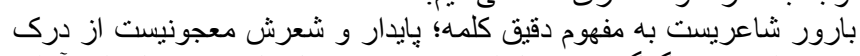

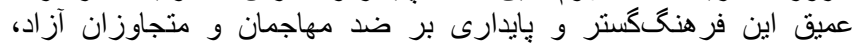

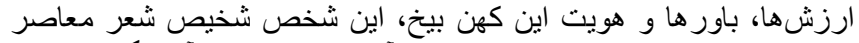

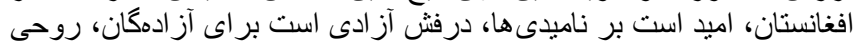

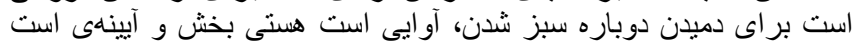
هويت نماى خر اسان. دئن

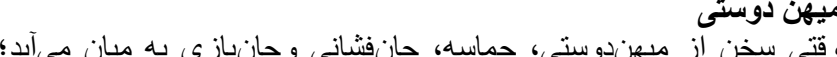

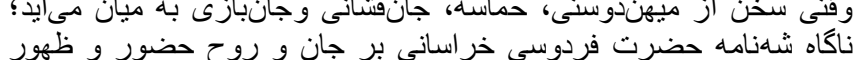

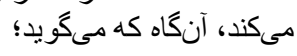

$$
\begin{aligned}
& \text { |ز همه سر بهاه سر نن به كوش دهيم } \\
& \text { از آن به كه كثور به دشمن دشن دهيم }
\end{aligned}
$$

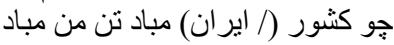

$$
\begin{aligned}
& \text { بر اين بوم و بر زنده يكى تن مباده) }
\end{aligned}
$$

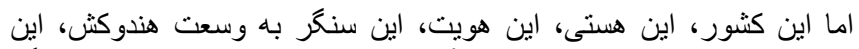

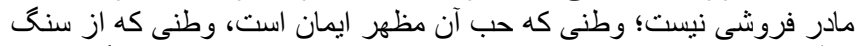

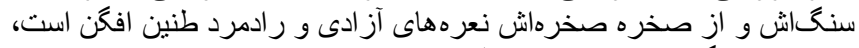

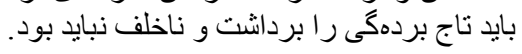

بر دار تاج بردگى را ا ! سر فروشى نيست 1

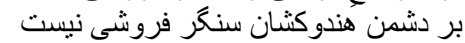

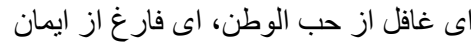

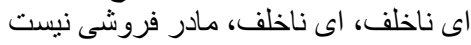

تمامى شعر ها از صحفه فيسبوى شخص شخيص شاعر كرفته شده است.
از صخره هايش نعره آز ادگى خيزد

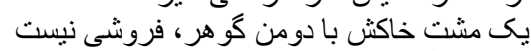

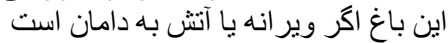

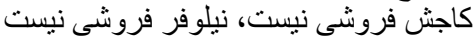

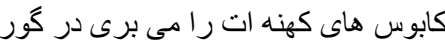
اين برجم اين تاريخ و اين كشور فروشى درئ نيست

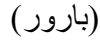

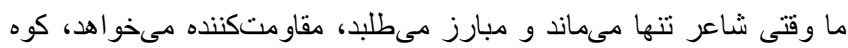

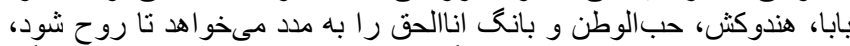

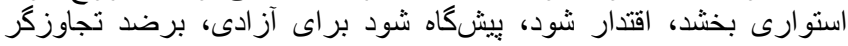

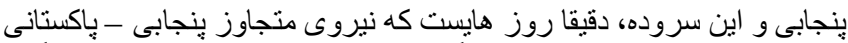

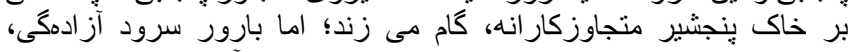

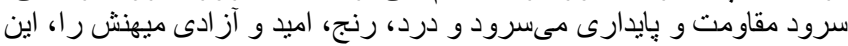

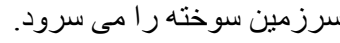

اى كوه بابا، شانه هاى استو ارم باش

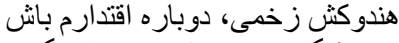

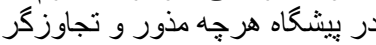

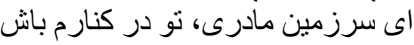

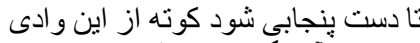

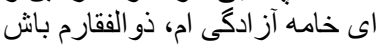

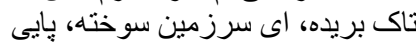

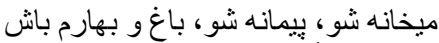

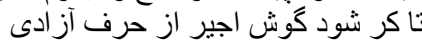

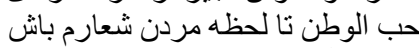

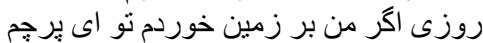

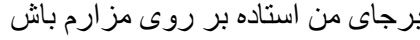

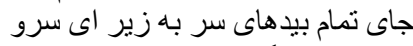

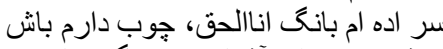

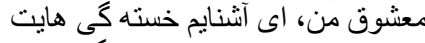

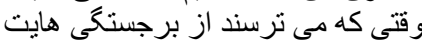

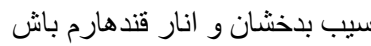

(بارور ) (بار)

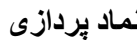

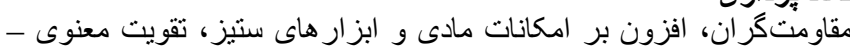

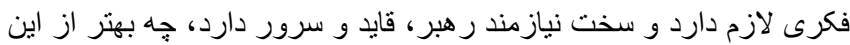

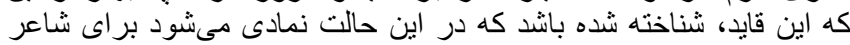

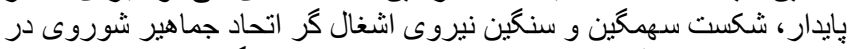

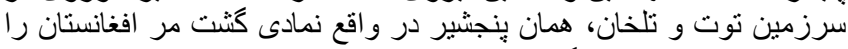

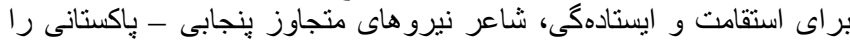

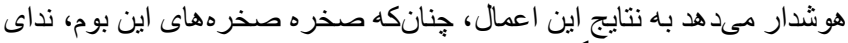

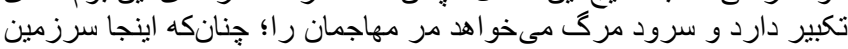

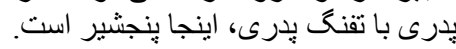

به كوش صخر النه اينجا نداى نكبير است

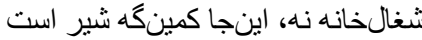

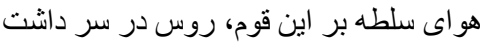

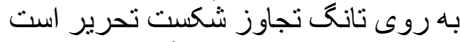

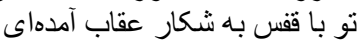

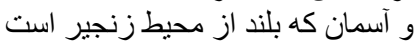

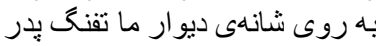

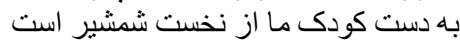

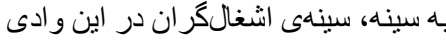

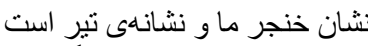

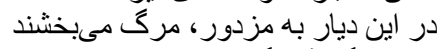

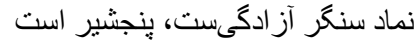
(بارور ) وقتى كه آسمان خر اسان سياه شد

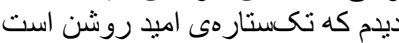

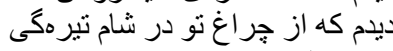
نورى بلند بود الز دئ

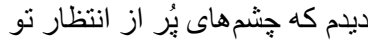

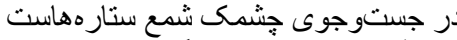

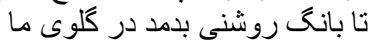
اي سنكر مبارزمى تئن بدم در كمان 


$$
\begin{aligned}
& \text { بنجشير قهرمان، ينجشير قهرمان }
\end{aligned}
$$

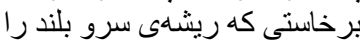

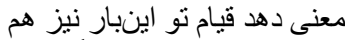

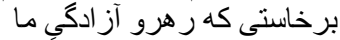

$$
\begin{aligned}
& \text { در تير هر اهذاى زمان هان كام نشيكند }
\end{aligned}
$$

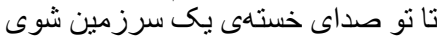

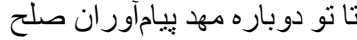

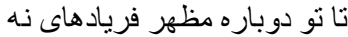

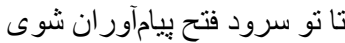

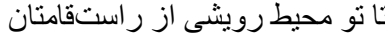

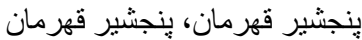

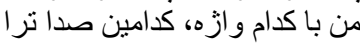

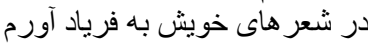

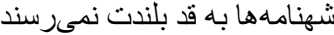

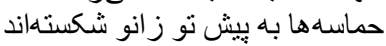

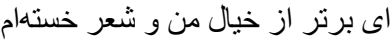

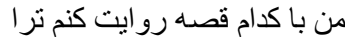

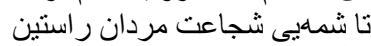

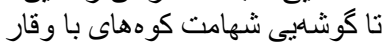

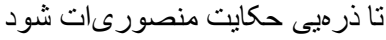

$$
\begin{aligned}
& \text { دارى درون سينهى تاريخ داستان }
\end{aligned}
$$

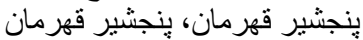

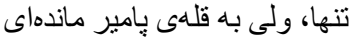

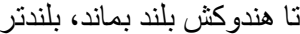

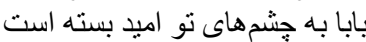

$$
\begin{aligned}
& \text { تا جشمك ستاره اين آسمان شوى }
\end{aligned}
$$

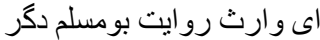

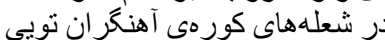

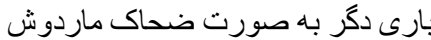

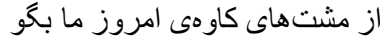

$$
\begin{aligned}
& \text { تا با طلوع صبح نو نورى شود أنو عيان }
\end{aligned}
$$

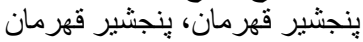

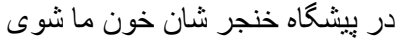

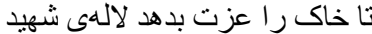

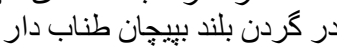

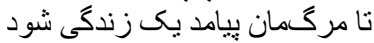

$$
\begin{aligned}
& \text { شوق انالحق آمده از مغز استخوان باندي }
\end{aligned}
$$

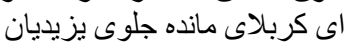

$$
\begin{aligned}
& \text { ينجشير قهرمان، ينجشير قهرمان يزئن }
\end{aligned}
$$

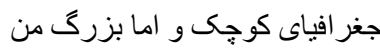

$$
\begin{aligned}
& \text { امروز باروايت تو ملتىست جمع بردي }
\end{aligned}
$$

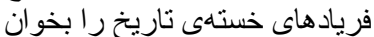

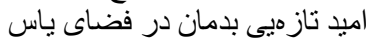

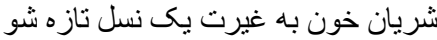

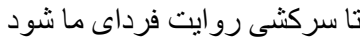

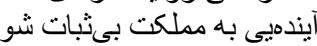

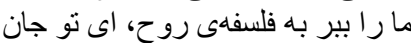

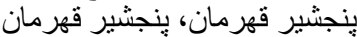

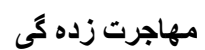

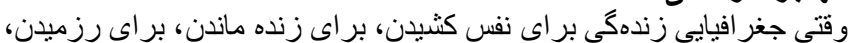

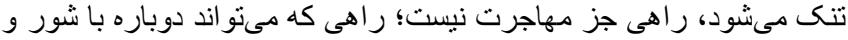

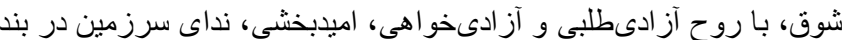

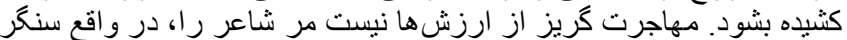

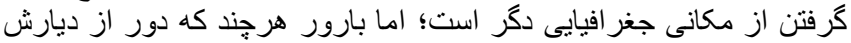

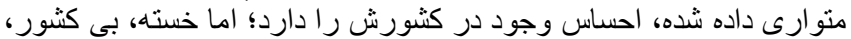

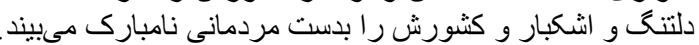

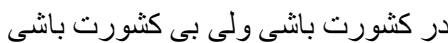

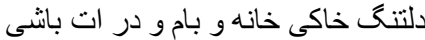

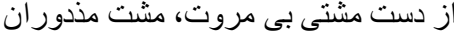

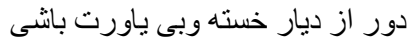

$$
\begin{aligned}
& \text { ساخت است وقتى باد كابل در سرت بارت آيد باني }
\end{aligned}
$$

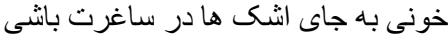

$$
\begin{aligned}
& \text { قر ان فروشى ميكند، ملا سياست باز }
\end{aligned}
$$

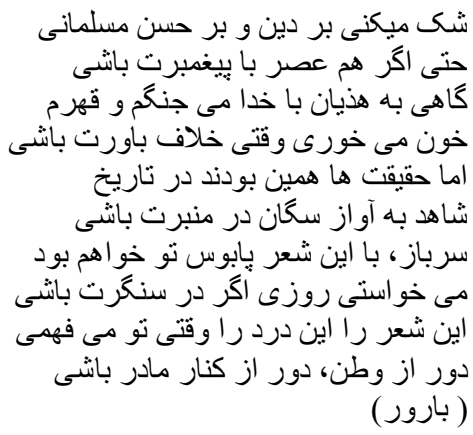

هماتندى به آزادهكان كَنشته

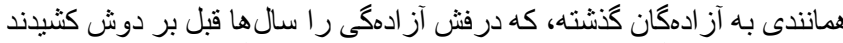

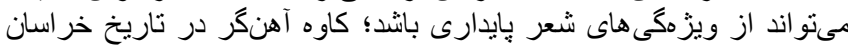

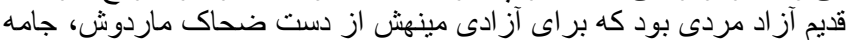

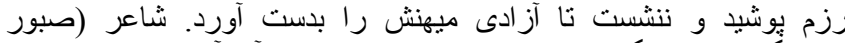

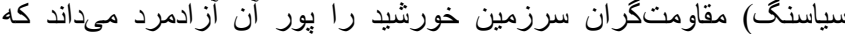

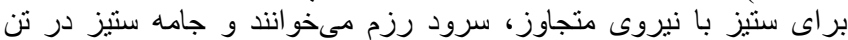

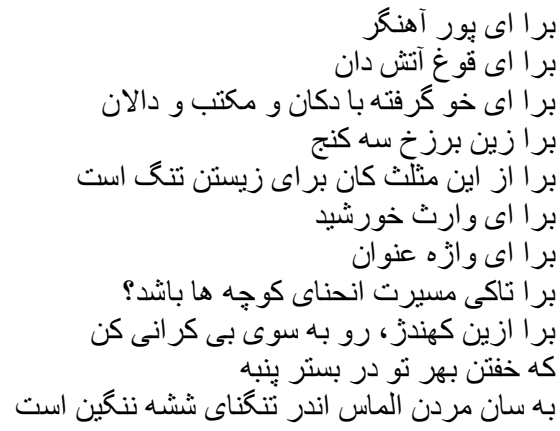

جشم و اميد به آزادى

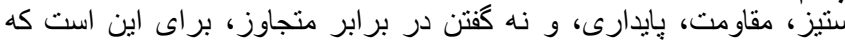

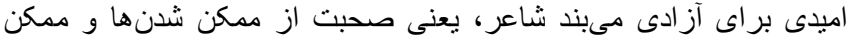

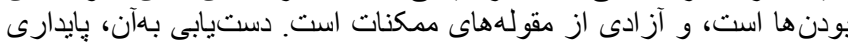

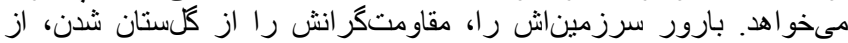

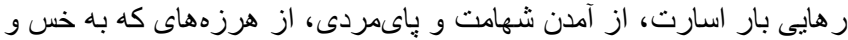

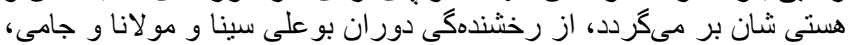

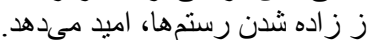

دوباره سبزتر از هر كلستان مى شئوى روزى

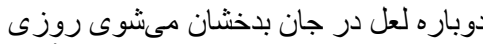

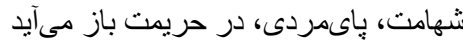

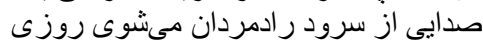

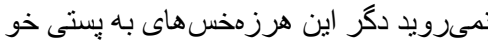

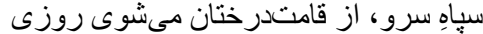

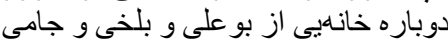

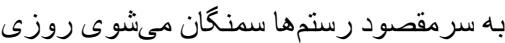

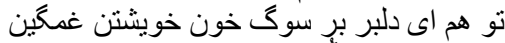

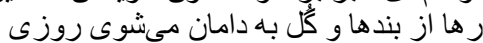

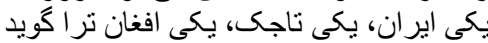

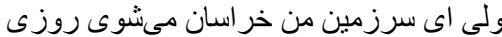

(بارور )

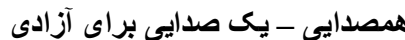

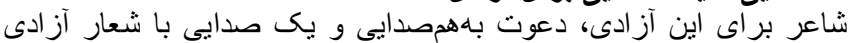

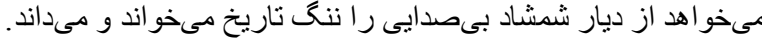

$$
\text { بى مداييى ننى تاريخ است، با فرياد باش }
$$

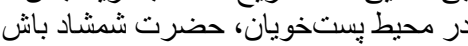

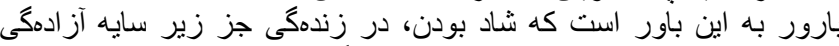

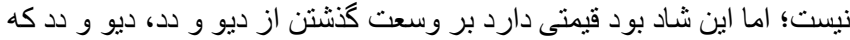

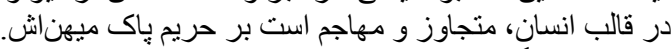

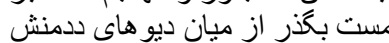

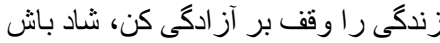




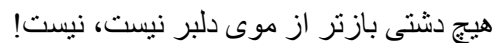

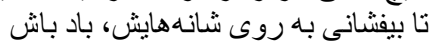

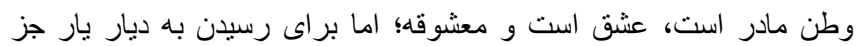

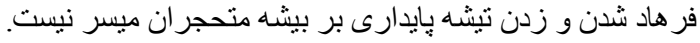

عشق از هر جيز اين دنيا ترا (شيرينتر) است

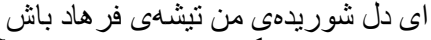

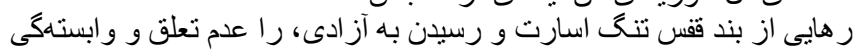

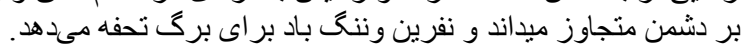

شرم بادا بر تعلق، ننگ بر و ابستكى!

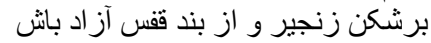

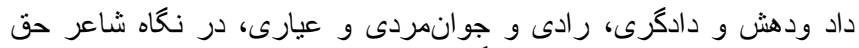

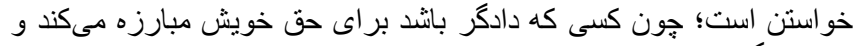

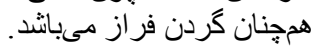

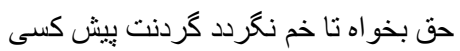
در فضاى نابر ابر ر راد باش و داد داد باش بـ

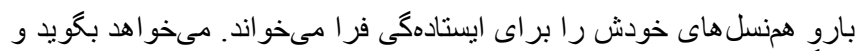

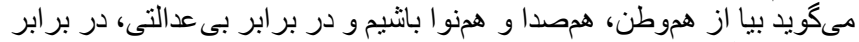

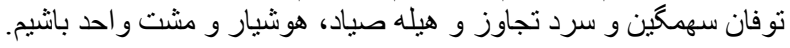

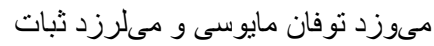

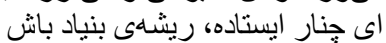

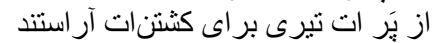

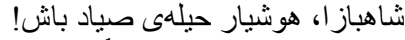

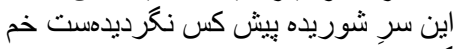

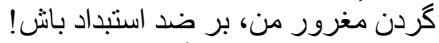

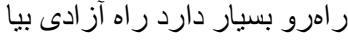
در مسير صفحهى امروز مارد ايجاد باد باش

\section{ستم ستيزى}

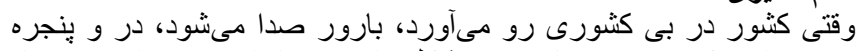

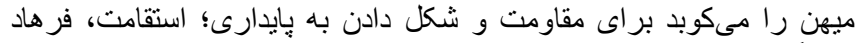

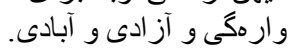

بارى دكر صداى نو ايجاد مى كنيم

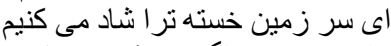

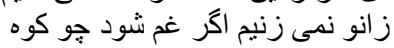

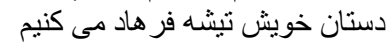

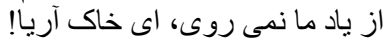

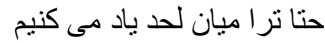

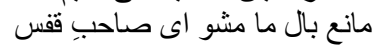

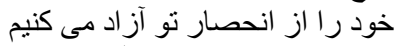

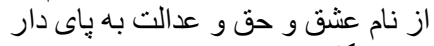

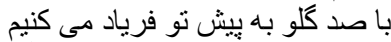

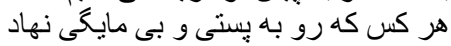

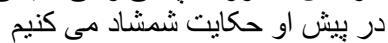

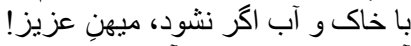

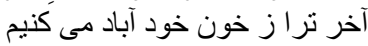

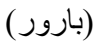

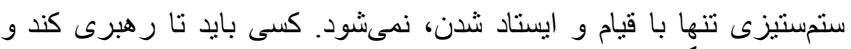

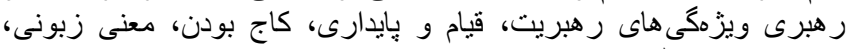
تاريخ و هستى ملتش ولثرى را بداند.

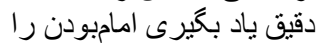

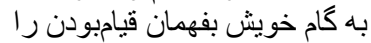

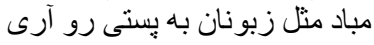

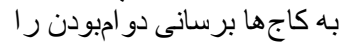

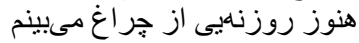

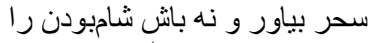

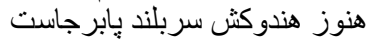

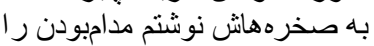
بخوان به خاك شهيدان خفته در سنكر

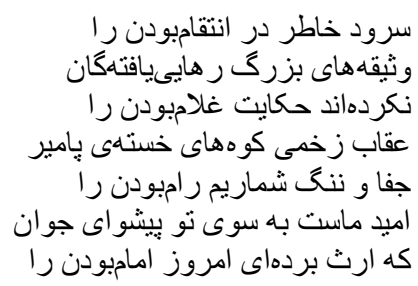

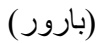

تقديس ارزش ها تائا

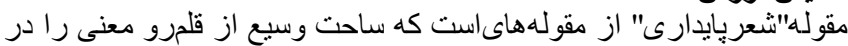

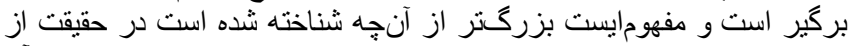

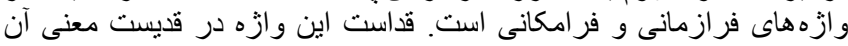

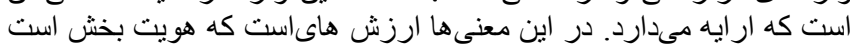

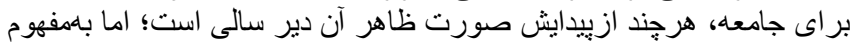

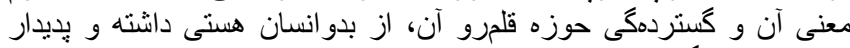

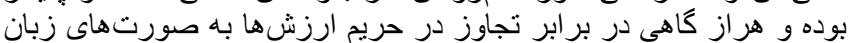

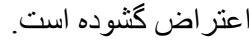

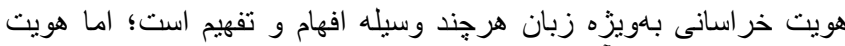

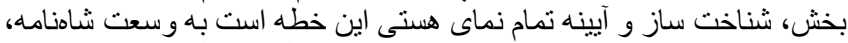

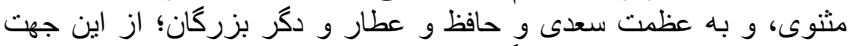

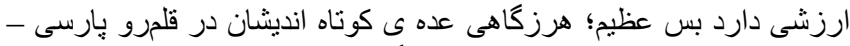

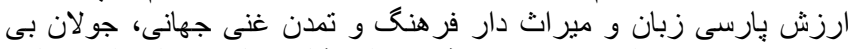

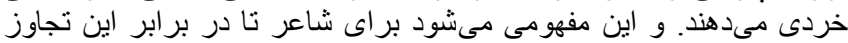

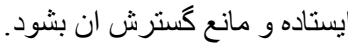

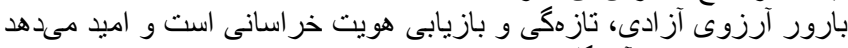

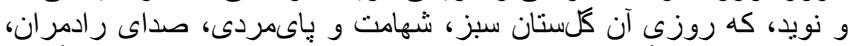

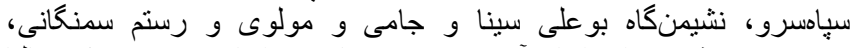

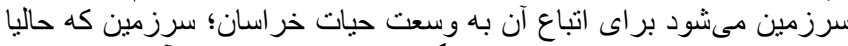

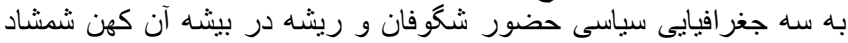
دارد، افغانستان، اير ان و تاجيكستئنان.

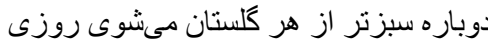

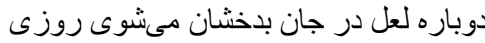

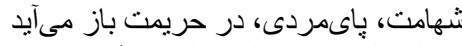

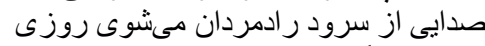

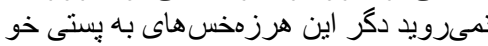

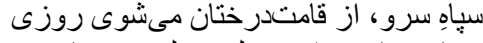

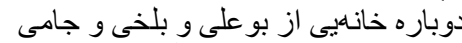

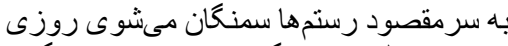

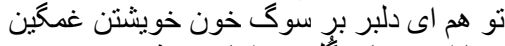

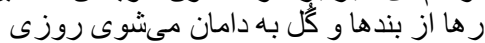

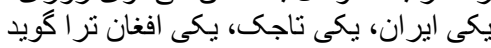

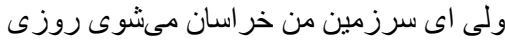

(بارور )

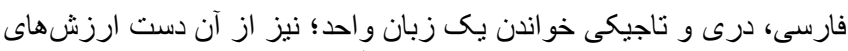

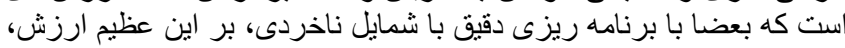

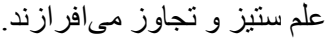

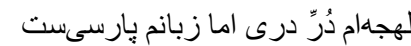

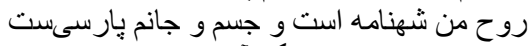

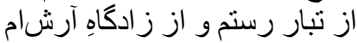

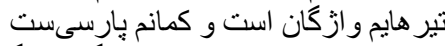

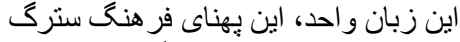

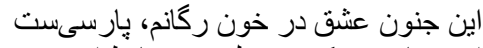

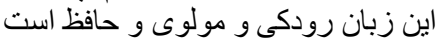

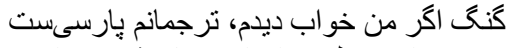

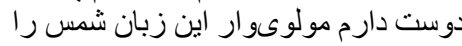

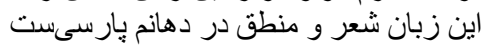

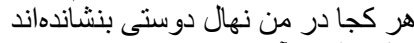

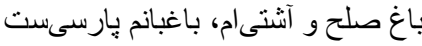

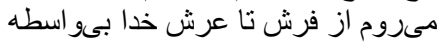

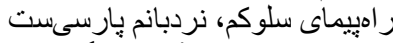

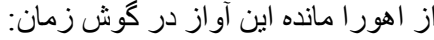

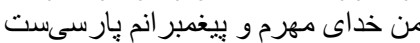

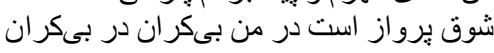




$$
\text { كفتر آز ادگى ام، آسمانم پֶارسىست (بارور ) }
$$

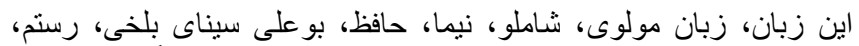

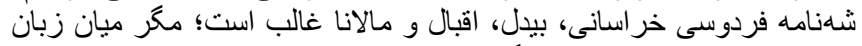

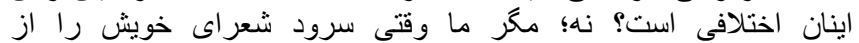

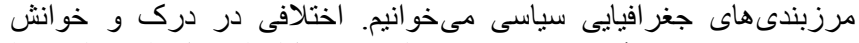

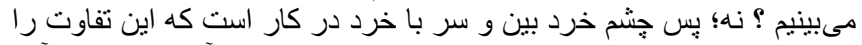

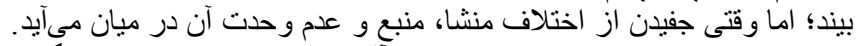

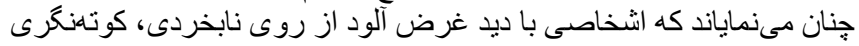
و بـىسو ادى است.

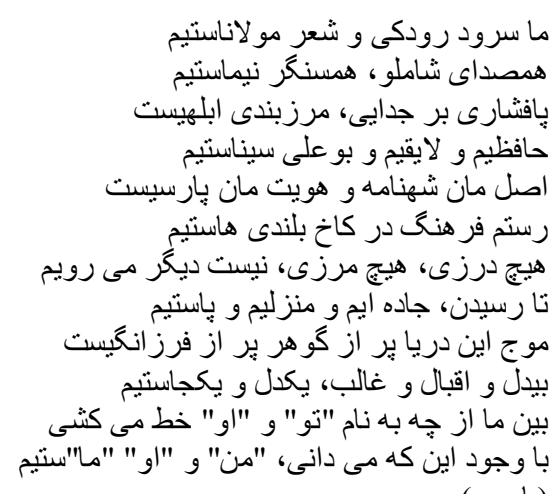

(بارور ) باورد)

تكريم انقلابيون

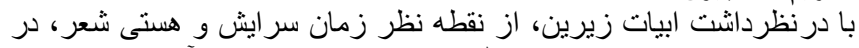

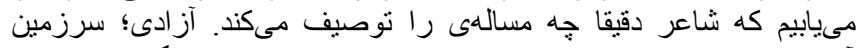

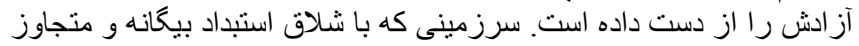

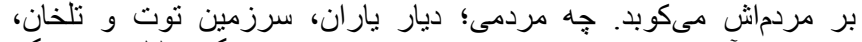

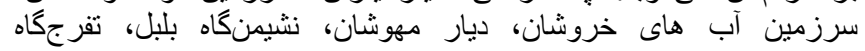

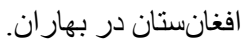

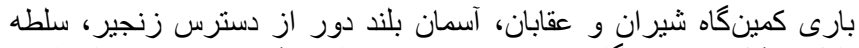

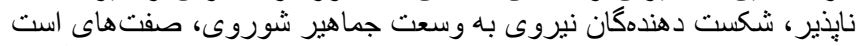

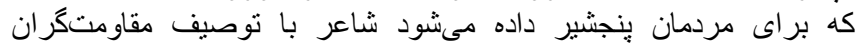
ينجشير ، در و اقع تنكريم و احتر ام مىدارد.

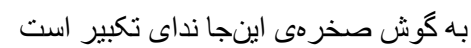

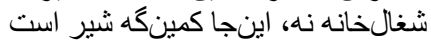

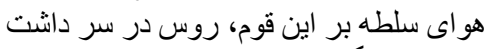

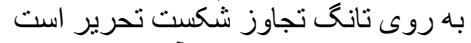

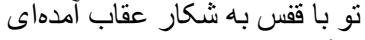

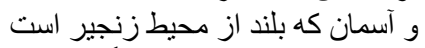

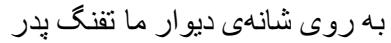

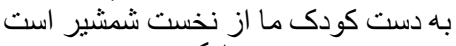

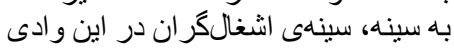

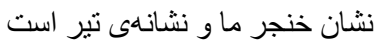

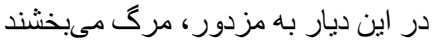

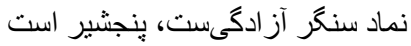
(بارور (آناد)

ستيز با متجاوز

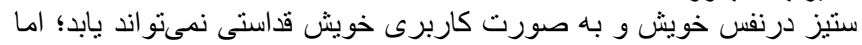

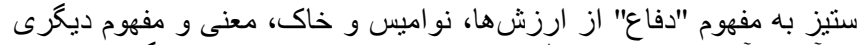

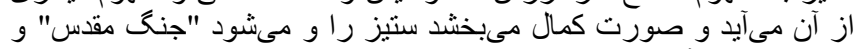

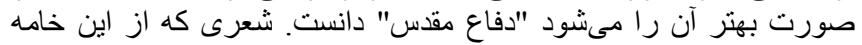

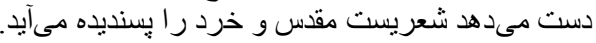

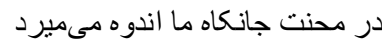

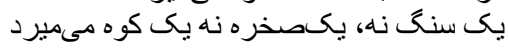

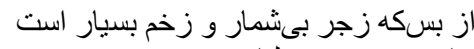

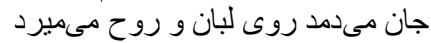

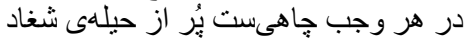

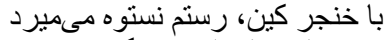

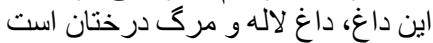

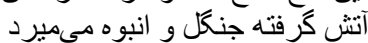

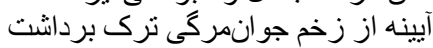

آهم درون سينهى مجروح مىميرد

(بارور ) (آمثرون

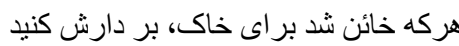

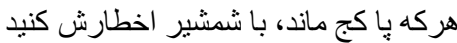

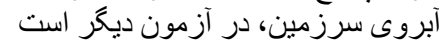

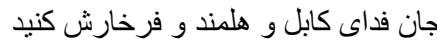

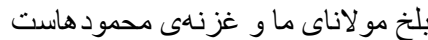
آنكه خو اب سلطه بر مان ما ديده بيدارش كنيد

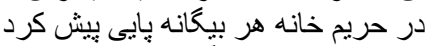

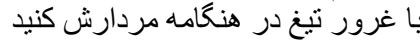

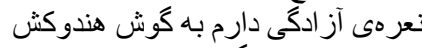

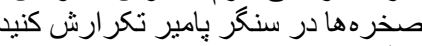

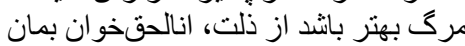

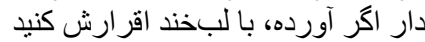

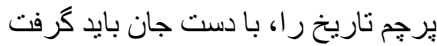

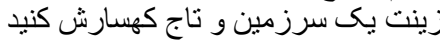

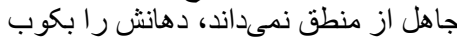

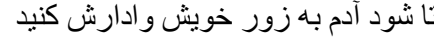

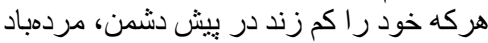

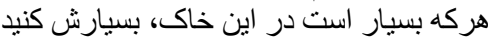

(بارور )

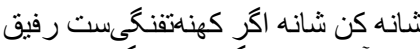

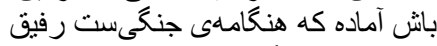

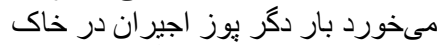

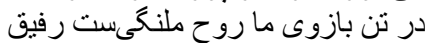

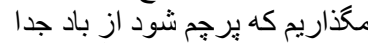

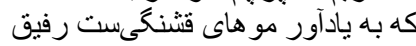

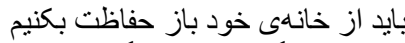

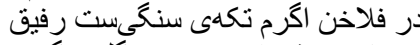

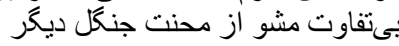

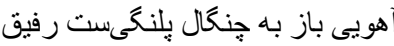

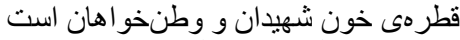

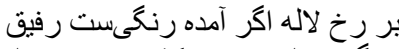

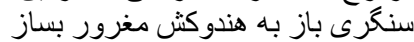

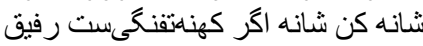
(بارور )

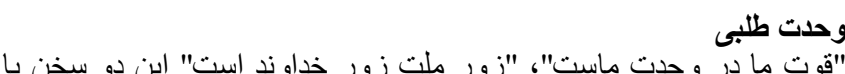

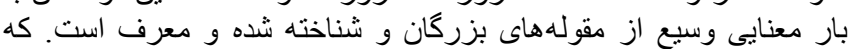

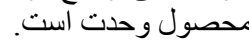

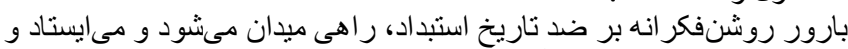

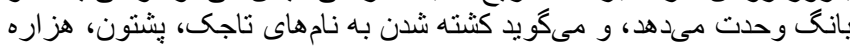

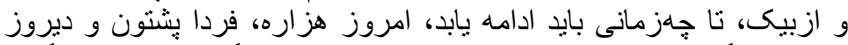

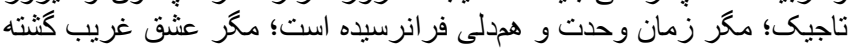

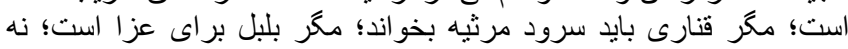

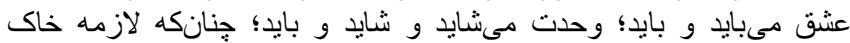

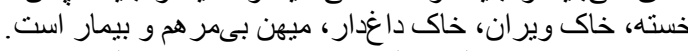

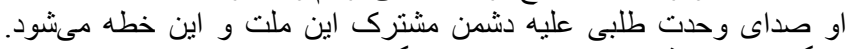

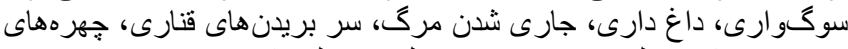

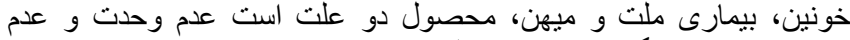

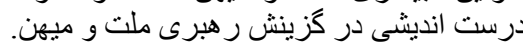

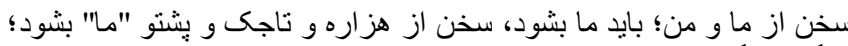

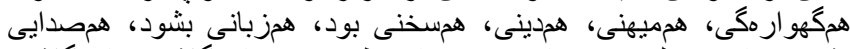

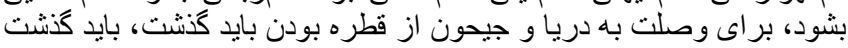

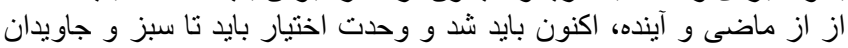
ماند.

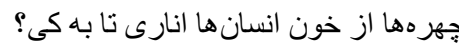

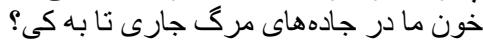

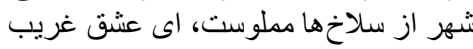

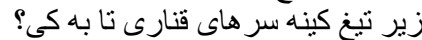

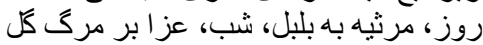

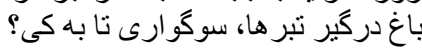

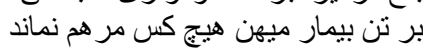




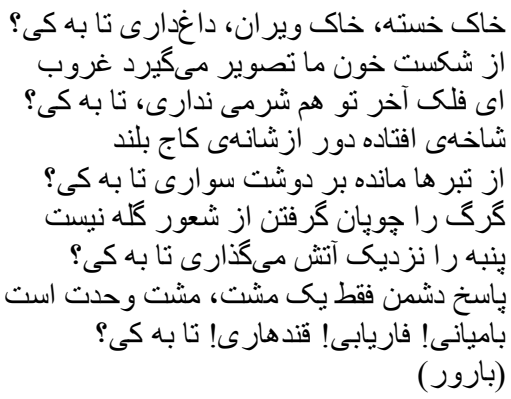

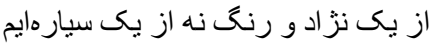

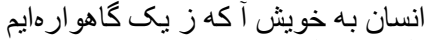

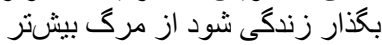

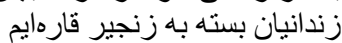

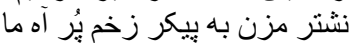

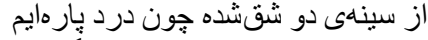

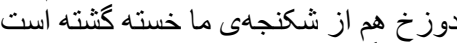

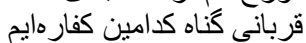

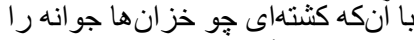

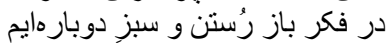

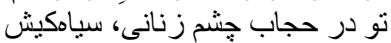

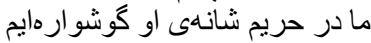

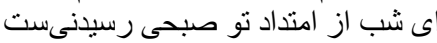

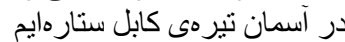

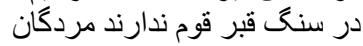

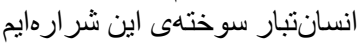

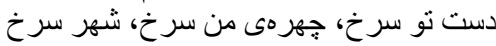

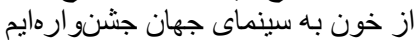

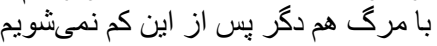

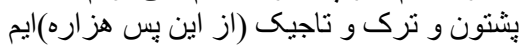
(بارور )

باز شو از دل يك قطره كه جيحون باثيح

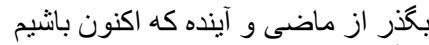

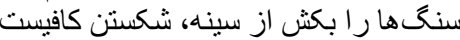

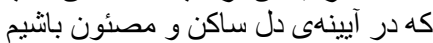

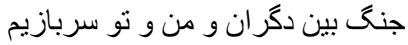

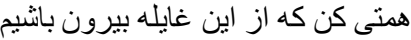

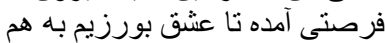

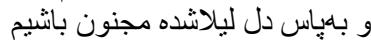

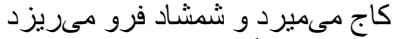

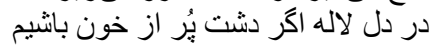

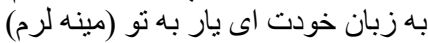
تا به كى در كرو تاجيك و وبشتون بارن بانشيم

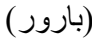

يش از از آنكه من و تو رهرو و رهبر باشيم

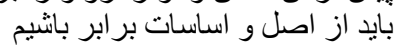

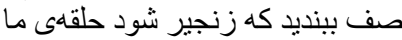

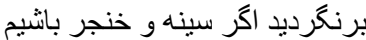

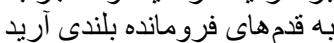

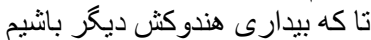

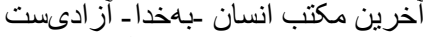

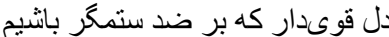

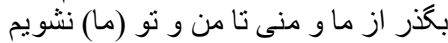

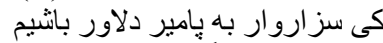

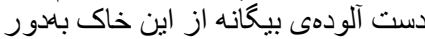

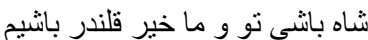

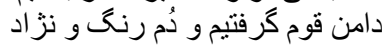

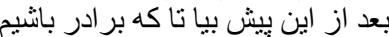

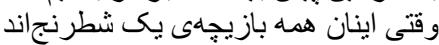

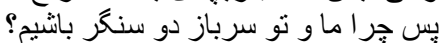
(بارور )
شعر بايدارى از كونههاى اعتر اض است در بر ابر استبداد و جور زمان،

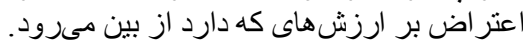

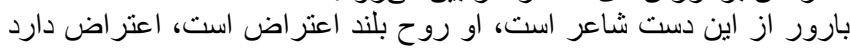

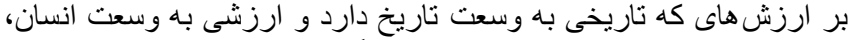

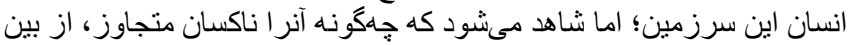

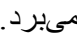

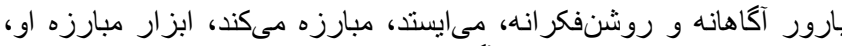

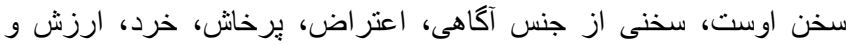

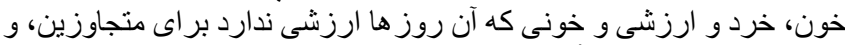

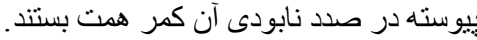

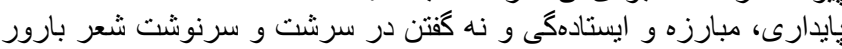

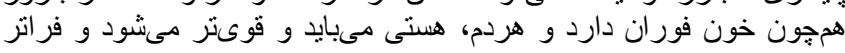
مىرود تا مرز هاى نوى ران داد در نوردد. هرد.

\section{Characteristics of Resistance poetry in Modern poetry of Afghanistan}

(in Najeeb Barwar poetry)

Abdul saboor salih

And Mirwais Shamal

Academic Member of Kabul Education University.

\section{Abstract}

Poetry is a form of protest against tyranny and the passage of time, the protest against the values disappears.

Barwar is such a poet, he is a high spirit of protest. $\mathrm{He}$ protests against the values that have background as vast as history and a value as vast as man, the man of this land; but he witnesses how the aggressor Naxan destroys it

Barwar consciously and intellectually, stands, and fights. The tool of his struggle is his word, word of the type of consciousness, protest, aggression, wisdom, value and blood. Wisdom and value and blood that has no value those days for the aggressors, and constantly they try to destroy them.

Perseverance, struggle, endurance, and saying "no" exist in nature and destiny of Barwar's poetry like an eruption of blood. And every time, he becomes stronger and goes beyond to cross new frontiers.

Key words: Najeeb Barwar, Resistance poetry, Modern poetry of Afghanistan

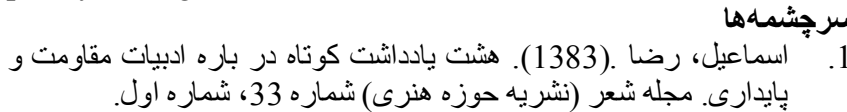

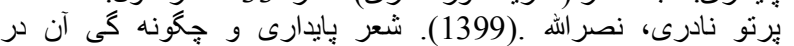
اففغانستان. كابل. انتشار ات: سعيد.

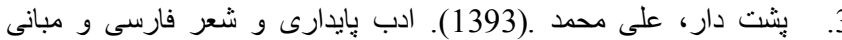

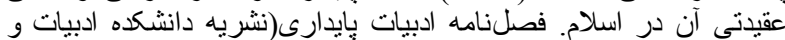

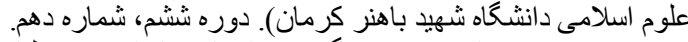

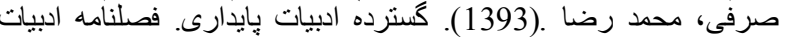
يايدارى(نشريه دانشكده ادبيات و علوم اسلامى دانشكاه شهيد باهنركرمان)، توروه ششم، شماره دهم.

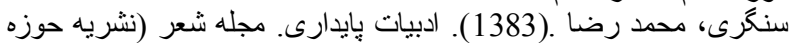

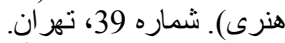
كيانى، حسين و سيد فضل فيل الله ميرقادرى .(1388). شهيد وجانباز در شعر

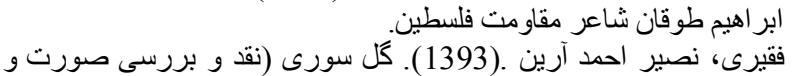
معناى شعر شعر عبدالقهار عاصىى). كابل: انتشار ات فر هنى (1391).

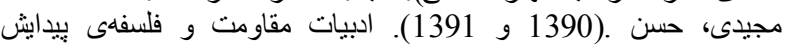

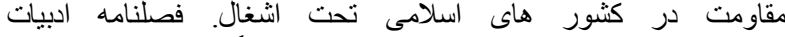
بايدارى(نشريه دانشكده ادبيات و علوم اسلامى دانشكاه شهيد باهنركرمان)،

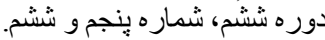

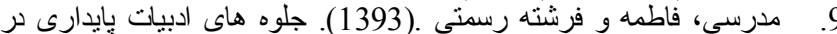

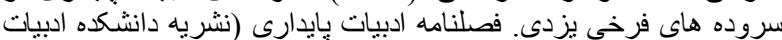

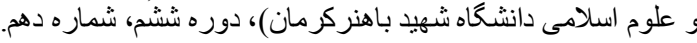

